\title{
Peningkatan Keaktifan dan Motivasi Belajar Mahasiswa melalui Pendekatan Kontekstual
}

\author{
Silviana Maya Purwasih ${ }^{(1)}$, Rani Kurnia Putri ${ }^{(2)}$ \\ Universitas PGRI Adi Buana Surabaya \\ J1. Ngagel Dadi III-B/ 37 Telp./Fax. (031) 822289873 Surabaya 60234 \\ e-mail: smaya@unipasby.ac.id dan rani@unipasby.ac.id
}

\begin{abstract}
ABSTRAK
Penelitian ini bertujuan untuk meningkatkan keaktifan dan motivasi belajar mahasiswa Program Studi Pendidikan Matematika di Universitas PGRI Adibuana pada mata kuliah Matematika Kejuruan melalui pendekatan kontekstual. Penelitian Ini merupakan Penelitian Tindakan Kelas dengan 2 siklus. Teknik pengumpulan data dilakukan melalui observasi, angket, dan dokumentasi, sedangkan teknik analisis data menggunakan reduksi data, penyajian data, dan penarikan kesimpulan. Hasil penelitian ini menunjukkan bahwa pendekatan kontekstual memberikan konstribusi dalam meningkatkan keaktifan dan motivasi belajar mahasiswa pada mata kuliah Matematika kejuruan. Secara klasikal, peningkatan tersebut dapat dilihat dari hasil data presentase angket keaktifan belajar mahasiswa pada siklus I mencapai 64,28\%, pada siklus II meningkat sebesar $12,43 \%$ menjadi $76,71 \%$, juga melalui presentase keseluruhan indikator motivasi belajar mahasiswa yang semula pada siklus I sebesar $62,10 \%$, pada siklus kedua meningkat sebesar $13,74 \%$ menjadi $75,84 \%$.
\end{abstract}

Kata kunci : keaktifan belajar, motivasi belajar, pendekatan kontekstual

\section{ABSTRACT}

This study aims to improve learning activity and learning motivation of Mathematics Education students' at PGRI Adi Buana University in Matematika Kejuruan course through a contextual approach. This research is a classroom action research in 2 cycles. The data was collected by using observation, questionnaire, and documentation, while data analysis techniques used data reduction, data presentation, and conclusion drawing. The results of this study indicated that the contextual approach contributed to improving student activeness and learning motivation in Matematika Kejuruan courses. In accordance with the classical, this increased can be seen from the results of the percentage of student learning activity questionnaire in the first cycle reached $64.28 \%$, in the second cycle increased by $12.43 \%$ to $76.71 \%$, also through the percentage of all student learning motivation indicators that were originally on cycle I was $62.10 \%$, in the second cycle it increased by $13.74 \%$ to $75.84 \%$.

Keywords : learning activity, learning motivation, contextual approuch

\section{PENDAHULUAN}

Perolehan hasil dan prestasi belajar yang tinggi sangat erat kaitannya dengan kesuksesan pendidikan. Faktanya tak hanya siswa tingkat menengah ke bawah yang memandang matematika sebagai momok yang sulit, hal yang serupa juga dialami oleh mahasiswa yang di jenjang perkuliahan. Konsep matematika pada umumnya masih bersifat abstrak, hal ini sering kali menyebabkan rendahnya motivasi belajar mahasiswa saat di kelas. Mahasiswa cenderung terlihat kurang berminat saat perkuliahan berlangsung, karena tidak memahami materi yang diterima secara kontekstual. Oleh karena itu, tak jarang ditemui penelitian di bidang pendidikan yang berfokus dalam mengungkap faktor-faktor yang mempengaruhi prestasi belajar tersebut. Di antara faktor tersebut adalah keaktifan dan motivasi belajar dari peserta didik. Keaktifan dan motivasi belajar memegang peranan penting bagi seseorang dalam mengembangkan kompetensi diri dan beradaptasi dengan lingkungan.

Slavin mendefinisikan motivasi sebagai proses di dalam diri individu yang aktif, mendorong, 
memberikan arah, dan menjaga perilaku setiap saat. (Prayitno \& dkk, 2017). Terdapat 3 fungsi motivasi menurut (Sardiman, 2014), yakni 1) mendorong manusia untuk melakukan suatu aktivitas, 2) Menentukan arah tujuan yang ingin dicapai, dan 3) Menyeleksi aktivitas apa saja yang perlu dilakukan untuk mencapai tujuan.

Sedangkan menurut (Usman, 2000) keaktifan adalah keterlibatan intelektual emosional siswa dalam kegitan belajar mengajar yang bersangkutan, asimilasi dan akomodasi kognitif dalam pencapaian pengetahuan, perbuatan serta pengalaman langsung terhadap balikannya (feed back) dalam pembentukan sikap". Dampak dari keaktifan ini akan dapat dilihat melalui aktivitas-aktivitas yang dilakukan oleh peserta, diantaranya seperti mencari sumber informasi yang dibutuhkan, menganalisi hasil eksperimen, membuat rangkuman, kliping, karya tulis, dan aktivitas sejenis lainnya, yang selanjutnya dapak ini akan menuntut pada keterlibatan peserta didik dalam proses KBM.

Rendahnya motivasi belajar ini dapat berdampak pada rendahnya keaktifan mahasiswa, yang pada akhirnya akan berdampak pada prestasi belajarnya di kelas. Hal ini sejalan dengan pendapat (Purwaningsih, 2018) yang dalam penelitiannya menyebutkan bahwa keaktifan dan motifasi belajar memiliki pengaruh yang signifikan terhadap hasil belajar siswa.

Oleh karena itu ketepatan dalam memilih dan memilah media, alat peraga, model serta pendekatan pembelajaran yang sesuai sangatlah penting. Salah satu solusi yang dapat dilakukan adalah dengan menerapkan pendekatan kontekstual dalam pembelajaran. Dalam penelitiannya (Fatiah \& dkk., 2014) menyebutkan, bahwa pendekatan kontekstual dapat meningkatkan motivasi dan hasil belajar siswa. Hal yang serupa juga diungkapkan (Mastari, 2019) dalam penelitiannya menyatakan aktivitas siswa dalam proses pembelajaran dengan menerapkan pendekatan kontekstual mengalami peningkatan.

(Komalasari, 2010), menyatakan bahwa pendekatan pembelajaran kontekstual adalah pendekatan pembelajaran yang menghubungkan antara materi yang dipelajari dengan kehidupan nyata siswa dalam kehidupan sehari hari, baik dalam lingkungan keluarga, sekolah, masyarakat maupun warga negara, dengan tujuan untuk menemukan makna materi tersebut bagi kehidupannya.

Menurut Johnson (dalam (Sugiyanto, 2009)) Pendekatan Kontekstual adalah sebuah proses pendidikan yang bertujuan menolong peserta didik untuk melihat makna yang terkandung dalam suatu materi dengan cara mengaitkan subjek-subjek akademik yang ada dengan konteks situasi pribadi, sosial dan budaya mereka.

Dengan demikian dapat dikatakan pendekatan kontekstual lebih banyak menekankan pada proses keterlibatan peserta didik secara utuh untuk dapat menemukan materi yang dipelajari dan menghubungkannya dengan situasi kehidupan nyata, sehingga mendorong mereka lebih aktif dalam kegiatan pembelajaran yang lebih bermakna.

Terdapat tujuh komponen utama yang harus dipenuhi dalam penerapan pendekatan kontekstual yakni: 1) Konstruktivisme (Constructivism), 2) Menemukan (Inquiry), 3) Bertanya (Questioning), 4) Masyarakat Belajar (Learning Community), 5) Pemodelan (Modeling), 6) Refleksi (Reflection), dan 7) Penilaian yang Sebenarnya (Authentic Assessment). (Muslich, 2012)

Berdasarkan latar belakang yang telah diuraikan di atas, maka masalah pokok yang akan dikaji pada penelitian ini adalah meningkatkan keaktifan dan motivasi belajar mahasiswa program studi Pendidikan Matematika di Universitas PGRI Adi Buana pada mata kuliah Matematika Kejuruan melalui pendekatan kontekstual.

\section{METODE PENELITIAN}

Penelitian yang bertujuan untuk meningkatkan keaktifan dan motivasi belajar mahasiswa program studi Pendidikan Matematika di Universitas PGRI Adi Buana pada mata kuliah Matematika Kejuruan ini merupakan penelitian tindakan kelas yang terdiri dari dua siklus, dimana tiap siklus terdiri dari $3 \mathrm{kali}$ pertemuan. Setiap pertemuan dilaksanakan berdasarkan rencana pembelajaran yang telah dipersiapkan sebelumnya, yakni dengan menerapkan pendekatan kontekstual. Menurut Arikunto setiap siklus tersebut terdiri empat tahapan yaitu: Tahap Perencanaan (Plan); Tahap Pelaksanaan (Act); Tahap Pengamatan (Observe); dan Tahap Refleksi (Reflect). (P., 2018)

Teknik pengumpulan data yang digunakan dalam penelitian ini adalah observasi, angket, dan dokumentasi, sedangkan teknik analisis data menggunakan reduksi data, penyajian data, dan penarikan kesimpulan. Pengamatan dilakukan dengan melihat indikator keaktifan dan motivasi mahasiswa dalam kelas. Setiap indikator diberikan nilai sesuai dengan pengamatan observer terhadap subyek penelitiannya dengan menggunakan skala Likert. 
Adapun angket motivasi yang digunakan pada penelitian ini merujuk pada angket yang dikembangkan oleh Githua, dengan memperhatikan 4 aspek motivasi, yaitu interest, relevance, perceived probability of success, dan satisfaction, sedangkan keaktifan mahasiswa diukur melalui lembar observasi.

Hasil data yang diperoleh, baik melalui observasi, angket maupun dokumentasi merupakan tolak ukur apakah tindakan yang dilaksanakan telah sesuai dengan perencanaan yang telah dibuat atau masih diperlukan adanya perbaikan pada siklus berikutnya. Suatu tindakan kelas dinyatakan berhasil jika tindakan tersebut mencapai kriteria yang ditentukan, yakni saat tingkat keaktifan dan motivasi belajar mahasiswa mencapai $75 \%$.

\section{HASIL DAN PEMBAHASAN}

Berdasarkan hasil observasi awal, diketahui bahwa tingkat keaktifan dan motivasi mahasiswa dalam mempelajari mata kuliah Matematika Kejuruan masih tergolong rendah. Oleh karenanya, peneliti mencoba untuk meningkatkan kedua aspek tersebut dengan menerapkan pendekatan kontekstual dalam perkuliahan.

Pada tahap Perencanaan, peneliti mempersiapkan perangkat pembelajaran yang dibutuhkan, kemudian menerapkan di kelas. Dari hasil pengamatan pada siklus I, diketahui secara garis besar kegiatan perkuliahan dengan menerapkan pendekatan kontekstual sudah dilaksanakan dengan baik. Adapun hasil penelitian pada siklus I adalah sebagai berikut:

\section{Persentase Keaktifan dan Motivasi Belajar Mahasiswa pada Siklus I}

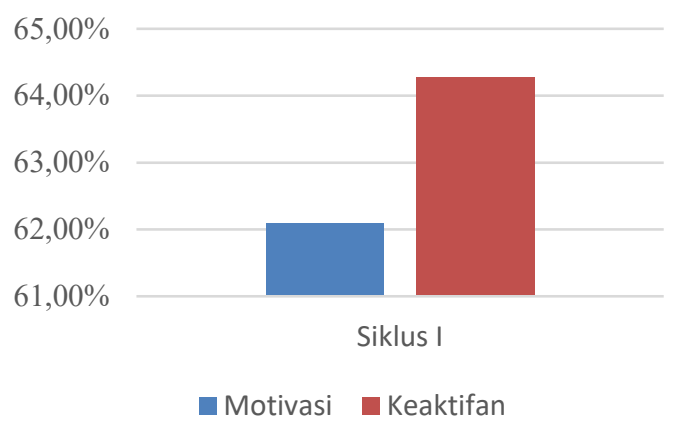

Gambar 1. Grafik persentase keaktifan dan motifasi belajar mahasiswa pada Siklus I

Dari hasil pengamatan di atas, dapat dilihat bahwa pada Siklus I tingkat keaktifan maupun motivasi belajar mahasiswa kurang dari 75\%, dengan kata lain siklus I belum berhasil, sehingga perlu dilakukan perbaikan-perbaikan agar diperoleh hasil yang lebih baik di siklus berikutnya.

Adapun hal-hal yang perlu diperbaiki untuk siklus berikutnya adalah peneliti perlu meningkatkan keterampilan mengoordinir mahasiswa dalam kelompok-kelompok diskusi serta memanage waktu perkuliahan dengan lebih baik lagi.

Perencanaan kegiatan pada siklus II dibuat berdasarkan hasil refleksi pada siklus I di atas. Dengan menerapkan revisi pada siklus II, proses perkuliahan dengan menerapkan pendekatan kontekstual menjadi lebih baik daripada siklus pertama, hal ini berdampak pada meningkatnya keaktifan dan motivasi belajar mahasiswa pada mata kuliah matematika kejuruan, yang dapat dilihat dari grafik berikut:

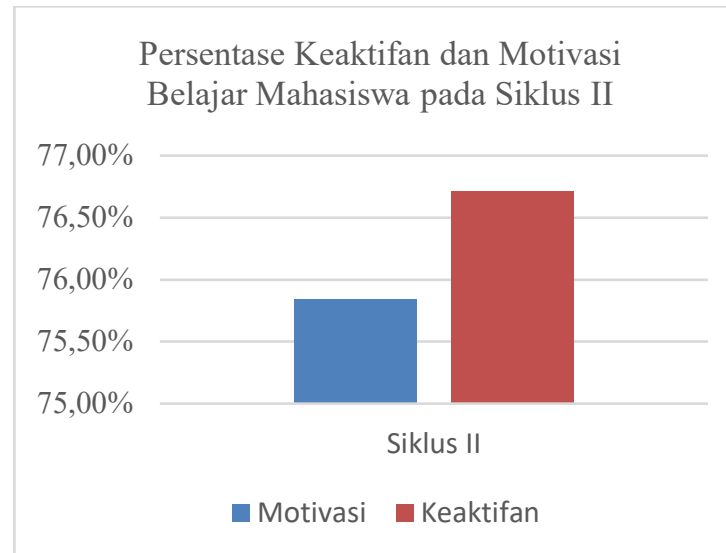

Gambar 2. Grafik persentase keaktifan dan motifasi Belajar Mahasiswa pada Siklus II

Melalui Gambar 2. di atas, terlihat bahwa persentase keaktifan dan motivasi belajar mahasiswa telah mencapai lebih dari 75\%, dengan demikian dapat dikatakan bahwa tindakan pada siklus II telah berhasil.

Adapun secara keseluruhan peningkatanpeningkatan yang ada mulai dari siklus I hingga siklus II dapat dilihat pada Tabel 1. Berikut:

Tabel 1. Persentase Peningkatan Keaktifan dan Motivasi Belajar Mahasiswa

\begin{tabular}{lccc}
\hline & $\begin{array}{c}\text { Siklus } \\
\text { I }\end{array}$ & $\begin{array}{c}\text { Siklus } \\
\text { II }\end{array}$ & Peningkatan \\
\hline \hline Motivasi & $62,10 \%$ & $75,84 \%$ & $13,74 \%$ \\
\hline Keaktifan & $64,28 \%$ & $76,71 \%$ & $12,43 \%$ \\
\hline
\end{tabular}

Meningkatnya keterampilan pengajar dalam menerapkan pendekatan kontekstual di kelas menjadi salah satu faktor utama dalam peningkatan keaktifan dan motivasi belajar mahasiswa, sehingga hal ini perlu digaris bawahi agar pada proses 
J Statistika Vol. 13 No. 2 (2020), Hal. 1-4

kegiatan perkuliahan berikutnya pendidik perlu mempertahankan dan memaksimalkan proses perkuliahan yang telah berjalan.

\section{KESIMPULAN DAN SARAN}

Berdasarkan hasil penelitian yang telah dipaparkan di atas, dapat disimpulkan bahwa pendekatan kontekstual berperan meningkatkan keaktifan dan motivasi belajar mahasiswa. Hal dikarenakan, pemahaman mahasiswa terhadap materi yang disampaikan menjadi lebih baik dari sebelumnya. Peningkatan tersebut dapat dilihat dari hasil data presentase angket keaktifan belajar mahasiswa pada siklus I mencapai $64,28 \%$, pada siklus II meningkat sebesar $12,43 \%$ menjadi $76,71 \%$, juga melalui presentase keseluruhan indikator motivasi belajar mahasiswa yang semula pada siklus I sebesar $62,10 \%$, pada siklus II meningkat sebesar $13,74 \%$ menjadi $75,84 \%$. Oleh karena itu, pendekatan kontekstual dapat dijadikan sebagai solusi dalam meningkatkan keaktifan dan motivasi belajar mahasiswa pada mata kuliah Matematika Kejuruan.

\section{DAFTAR PUSTAKA}

Fatiah, Y. N., \& dkk. (2014). Penerapan Pendekatan Kontekstual dalam Meningkatkan Motivasi Belajar Matematika Siswa Kelas III SD. Jurnal FKIP UNS, Volume 2(No.2). Komalasari, K. (2010). Pembelajaran Kontekstual: Konsep dan Aplikasi. Bandung: Refika Aditama.

Mastari. (2019). Implementasi Pendekatan Kontekstual untuk Meningkatkan Prestasi Belajar Matematika Siswa Kelas V SDN 1 Sesela Kecamatan Gunungsari Kabupaten Lombok Barat Tahun Pelajaran 2018/2019. Journal of Classroom Action Research, 6671.

Muslich, M. (2012). Pembelajaran Berbasis Kompetensi dan Kontekstual. Jakarta : Bumi Aksara.

Nasution. (2010). Berbagai Pendekatan dalam Proses Belajar Mengajar. Jakarta: Bumi Aksara.

P., S. M. (2018). Penerapan Pendekatan Contextual Teaching and Learning Sebagai Upaya Meningkatkan Prestasi Belajar Matematika Siswa. Jurnal Buana Matematika, Volume 8(No. 1).

Prayitno, S. H., \& dkk. (2017). Dasar Proses Pembelajaran Matematika I. Surabaya: Adi Buana University Press.

Purwaningsih, S. (2018). Pengaruh Keaktifan dan Motivasi Terhadap Hasil Belajar Siswa www.unipasby.ac.id

dalam Penerapan Model Pembelajaran Kooperatif Tipe STAD Materi Turunan Fungsi Pada Siswa Kelas XI IS 2 SMAN 15 Semarang. Jurnal Karya Pendidikan Matematika, Volume 5(No. 2), 63-67.

Sardiman. ( 2014). Interaksi Dan Motivasi Belajar Mengajar. Jakarta: PT Raja Grafindo Persada.

Sugiyanto. (2009). Model-model Pembelajaran Inovatif. Surakarta: UNS.

Usman, M. U. (2000). Menjadi Guru yang Profesional. Bandung: Remaja Rosdakarya. 